\title{
BIOLOGIC WIDTH CONCEPT IN GINGIVECTOMY (CASE REPORT)
}

\author{
Desy Fidyawati \\ Periodontology Department, Faculty of Dentistry, Universitas Prof. Dr. Moestopo (Beragama), Jakarta \\ Corresponding: desyfidyawati@gmail.com
}

\begin{abstract}
Background: relationship between periodontal tissue and aesthetic considerations is an important thing to determine the form, function and aesthetics of periodontal tissue itself. For orthodontic cases with gingival enlargement, using the biological width concept in gingivectomy to facilitate an optimal oral hygiene maintenance, function and aesthetic. Bone sounding before gingival recontouring is dictated by the distance from the gingiva crest to alveolar crest. Recommended distance between margins restoration and alveolar bone crest is $3 \mathrm{~mm}$ to avoid breaching the biologic width. Case report: case 1: A 21 years old female patient whom referred from orthodontist with gingival enlargement in upper front teeth after treated with fixed orthodontic for 1.5 years. PBI: 1,6. After clinical examination, bone sounding was performed $=7 \mathrm{~mm}$ and gingivectomy without ostectomy was determined. Case 2: A male patient, 24 years old, with gingival enlargement in upper front teeth while treated with fixed orthodontic. After determined the problem, bone sounding $(6 \mathrm{~mm})$ was performed along with gingivectomy without ostectomy also for anterior upper right site. Conclusion: the purpose of this report is to provide a diagnostic rationale for gingival recontouring. When gingivectomy is determined, the concept of biological width must be applied achieve a harmonious gingival contour with an optimal oral hygiene maintenance.
\end{abstract}

Keywords: biologic width, gingival recontouring, orthodontic treatment

\begin{abstract}
ABSTRAK
Latar belakang: hubungan antara jaringan periodontal dan pertimbangan estetika merupakan hal yang penting untuk menentukan bentuk, fungsi dan estetika. Pemilihan metode perawatan dengan konsep biologic width dalam terapi periodontal untuk kasus ortodontik yang disertai pembesaran gingiva adalah untuk memudahkan penjagaan oral hygiene yang memadai serta meningkatkan fungsi dan estetika dari mukosa jaringan lunak. Tindakan bone sounding pada gingival recontouring adalah menentukan jarak dari puncak gingiva ke puncak tulang alveolar. Jarak yang direkomendasikan antara puncak margin gingiva dan crest tulang alveolar adalah $3 \mathrm{~mm}$. Laporan kasus: kasus 1: Pasien wanita berusia 21 tahun konsul dari bagian ortodontik dengan keluhan adanya pembesaran gingiva pada gigi depan 11-25, setelah perawatan dengan alat ortodontik cekat selama 1,5 tahun. PBI: 1,6. Tata laksana kasus: Setelah dilakukan pemeriksaan klinis, perawatan selanjutnya adalah melakukan tindakan bone sounding yang didapatkan hasil $7 \mathrm{~mm}$, dilanjutkan dengan prosedur bedah gingivektomi tanpa ostektomi. Kasus 2: Pasien pria berusia 24 tahun datang dengan keluhan pembesaran gingiva karena perawatan ortodontik cekat.Tata laksana kasus: Setelah dilakukan pemeriksaan awal klinis dengan $\mathrm{PBI}=0,0$ selanjutnya dilakukan prosedur bone sounding untuk gigi 13-23 dengan hasilnya $6 \mathrm{~mm}$. Selanjutnya dilakukan prosedur bedah gingivektomi yang juga tanpa ostektomi. Kesimpulan: tujuan dari laporan kasus ini adalah untuk menunjukkan pentingnya konsep biological width dalam perawatan gingivektomi untuk mendapatkan gingiva yang sehat dan kontur yang baik sehingga memudahkan pasien dalam menjaga oral hygiene. Prosedur bedah gingivektomi menerapkan konsep biologic width melalui tindakan bone sounding.
\end{abstract}

Kata Kunci: biologic width, gingival recontouring, terapi ortodontik

\section{BACKGROUND}

$\mathrm{B}$ iological width defined as the dimension of space that the healthy gingival tissue occupy above the alveolar bone. ${ }^{1}$ It is also a dimension of the soft tissue, which attached to the coronal tooth towards the crest of the alveolar bone. It can be identified for each individual patient by probing to the bone level and substracting the sulcus depth from the 
resultant measurement. ${ }^{2}$ The biologic width of gingiva is commonly stated to be $2.04 \mathrm{~mm}$ (Fig.1), which represents the sum of the epithelial and connective tissue measurements. ${ }^{1}$

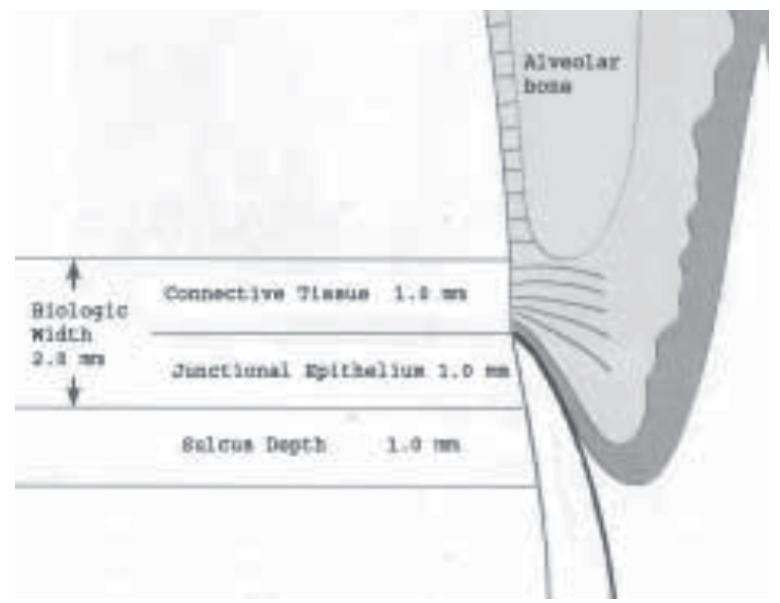

Figure 1. Biologic Width on upper teeth ${ }^{2}$

There is a definite proportional relationship between the alveolar crest, the connective tissue attachment, the epithelial attachment, and the sulcus depth. Adequate relationship between periodontal tissue and aesthetic considerations is an important thing to determine the form, function and aesthetics. They reported the following mean dimensions: A gingival sulcus depth of $0.69 \mathrm{~mm}$, an epithelial attachment of $0.97 \mathrm{~mm}$, and a connective tissue attachment of $1.07 \mathrm{~mm}$. It has been shown that $3 \mathrm{~mm}$ between the preparation margin and alveolar bone maintains periodontal health for 4 to 6 months. ${ }^{3}$ It is essential for preservation of periodontal health and removal of irritation that might damage the periodontium. The millimeter that is needed from the bottom of the junctional epithelium to the tip of the alveolar bone is held responsible for the lack of inflammation and bone resorption, and as such the development of periodontitis, which in turn may impact our approach to surgical intervention. ${ }^{1}$

\section{Bone Sounding}

Bone sounding also known as transgingival probing, was advocated by Greenberg et al as estimator of alveolar bone level. The biologic width can be identified by probing under local anesthesia to the bone level (referred to as "sounding to bone") and subtracting the sulcus depth from the resulting measurement. If this distance is less than $2 \mathrm{~mm}$ at one or more locations, a diagnosis of biologic width violation can be confirmed. This measurement must be performed on teeth with healthy gingival tissues and should be repeated on more than one tooth to ensure accurate assessment, and reduce individual and site variations. ${ }^{1}$. In this case reports, bone sounding applied by measurement of bone probing depth by transgingival probing with periodontal probe was used. Local anastesia was administered prior to measure bone probing depth. The deepest depth at which the probe met strong resistance from contact to the bone was recorded and perpendicular to it probing was done. ${ }^{1}$

\section{Correction of biologic width violation}

Biologic width violations can be corrected by either surgically removing bone away from proximity to the restoration margin, or orthodontically extruding the tooth thus moving the margin away from the bone.

\section{Surgical crown lengthening is designed to increase the clinical crown length.}

Selecting the case for surgical crown lengthening should be needed an analysis of the individual case with regard to crown-root-alveolar bone relationship,

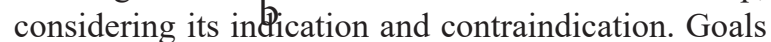
of crown lengthening such as facilitating an ideal restorative result through gain access to subgingival caries, root resorption and/or post/pin restoration, also preserving the health of the periodontium by adjusting bone height and soft tissues position away from the proposed crown margins to prevent biologic width impingement after crown sementation and eliminate chronic irritation/inflammation, tissue discomfort and pain, and bone loss. ${ }^{2}$ Indications: ${ }^{4}$

1. Inadequate clinical crown for retention due to extensive caries, subgingival caries or tooth fracture, root perforation, or root resorption within the cervical $1 / 3$ rd of the root in teeth with adequate periodontal attachment.

2. Short clinical crowns.

3. Placement of sub gingival restorative margins.

4. Unequal, excessive or unaesthetic gingival levels for esthetics.

5. Planning veneers or crowns on teeth with the gingival margin coronal to the cemeto enamel junction (delayed passive eruption).

6. Teeth with excessive occlusal wear or incisal wear.

7. Teeth with inadequate interocclusal space for proper restorative procedures due to supraeruption.

8. Restorations which violate the biologic width.

9. In conjunction with tooth requiring hemisection or root resection.

10. Assist with impression accuracy by placing crown margins more supragingivally.

Contraindications: ${ }^{4}$

1. Deep caries or fracture requiring excessive bone removal. 
2. Post-surgery creating unaesthetic outcomes.

3. Tooth with inadequate crown root ratio (ideally $2: 1$ ratio is preferred)

4. Non restorable teeth.

5. Tooth with increased risk of furcation involvement.

6. Unreasonable compromise of esthetics.

7. Unreasonable compromise on adjacent alveolar bone support.

\section{External bevel gingivectomy}

Gingivectomy is a very successful and predictable surgical procedure for reconstruction of biologic width; however, it can be used only in situations with hyperplasia or pseudo pocket $(>3 \mathrm{~mm}$ of biologic width) and presence of adequate amount of keratinized tissue. ${ }^{5}$

\section{Internal bevel gingivectomy}

Reduction of excessive pocket depth and exposure of additional coronal tooth structure in the absence of a sufficient zone of attached gingiva with or without the need for correction of osseous abnormalities requires internal-bevel gingivectomy. ${ }^{2}$

\section{Gingival Overgrowth}

The use of orthodontic appliances, as well as other mechanical procedures, prone to cause a response in the gingival soft tissue. Such a response can be positive as facilitate the movement of teeth, or the negative of which are generally obtained from the attachment of orthodontic appliances on teeth that resulted ineffective of removal of plaque biofilm. Inflammation of the gingival may cause inflammation of periodontal, but gingival inflammation not always became a periodontitis. Patients with orthodontic treatment also experience inflammation of the gingival tissue at risk of damage periodontal. ${ }^{6}$

Gingival overgrowth during orthodontic treatment is generally recognized as gingival inflammation caused by the accumulation of plaque and bacteria, also caused by the difficulty of maintaining oral hygiene in patients with orthodontic treatment, the volume of gingival enlargement can occur in patients with good oral hygiene, with no clinical signs such as inflammation of the gingiva. ${ }^{7}$ Gingival enlargement during orthodontic treatment may inhibit the maintenance of oral hygiene, furthermore may cause damage to the tissues periodontal. ${ }^{8}$ In esthetic areas, a longer healing period is recommended to prevent recession. In cases where the gingival enlargement becomes more fibrous, surgical treatment may be determined. ${ }^{1}$ Generally, surgical treatments were selected in the case of gingival enlargement is gingivectomy and gingivoplasty, which is one of the periodontal surgical technique using a scalpel under local anesthesia, followed by the disposal of mechanical plaque and also control oral hygiene. ${ }^{9}$ Shobha et al. in a study on clinical evaluation of crown lengthening procedure had concluded that the biologic width can be reestablished to its original vertical dimension along with $2 \mathrm{~mm}$ gain of coronal tooth structure at the end of six months. ${ }^{10}$ This case report will discuss the importance of applying the concept of biologic width in surgical procedures gingivectomy and management of the case.

\section{CASE REPORT}

Case 1: A 21 years old female patient referred from orthodontist with gingiva enlargement in upper front teeth after treated with fixed orthodontic for 1.5 years. The patient presented good general health. Clinical examination showed there is a fibrotic gingiva at the anterior upper site with Papillary Bleeding Index (PBI): 1,6. Plaque Index (PI): 0,4. Calculus Index (CI): 0,2. Apical radiolucency is not showed at radiographic. Pre operative intraoral examination showed gingival oedem and fibrous (Fig. 2 ). After determining the problem, the diagnosis, treatment planed and the surgical technique were determined. Scaling and dental health education was applied at initial periodontal treatment phase along with maintenance phase then gingivectomy was applied at phase II or surgical phase (Fig.3). Bone sounding was performed to measure the distance between alveolar and margin gingiva. Diagnosis for this case was gingival enlargement caused by plaque and calculus, exacerbated by the pressure of the orthodontic appliance. Bone sounding 11-15, 21-25 $=7 \mathrm{~mm}$, based on that, $\mathbf{a}=\mathbf{5} \mathbf{m m ~} \mathbf{d}=\mathbf{2} \mathbf{m m}$, it means the structure of the tooth to be exposed is $\mathbf{3} \mathbf{m m}$ (Fig. 4). Gingivectomy without ostectomy was performed by surgical blade no.15 to make an external beveled incision which is about 45 degrees toward the long axis of tooth with an apico-coronal direction.

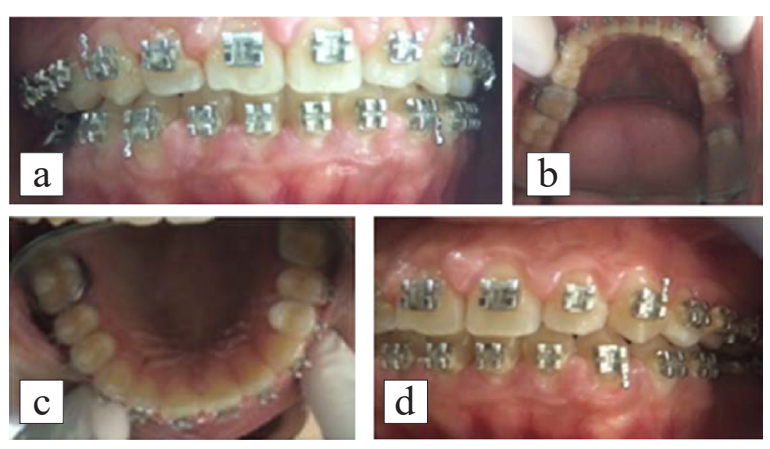

Figure 2. (a-d) Clinical examination for gingival disorder in anterior region, upperand lower - gingival fibrous, oedem) 


\section{Treatment Plan-}

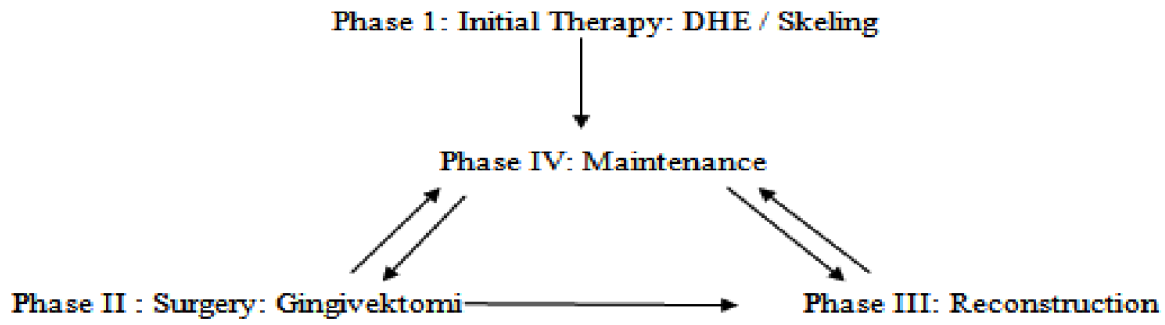

\begin{tabular}{l|l|l|l|l}
5432 & 12345 \\
\hline 54321 & 1234
\end{tabular}

36- Implant/Bridge work

\section{Bone Sounding}

\begin{tabular}{|l|l|l|l|}
\hline Gigi 11-15 & Mesio Labial & Mid Labial & Disto Labial \\
\hline Pocket Depth & $5 \mathrm{~mm}$ & $5 \mathrm{~mm}$ & $5 \mathrm{~mm}$ \\
\hline Bone Sounding & $7 \mathrm{~mm}$ & $7 \mathrm{~mm}$ & $7 \mathrm{~mm}$ \\
\hline
\end{tabular}

\begin{tabular}{|l|l|l|l|}
\hline Gigi 21-25 & Mesio Labial & Mid Labial & Disto Labial \\
\hline Pocket Depth & $5 \mathrm{~mm}$ & $5 \mathrm{~mm}$ & $5 \mathrm{~mm}$ \\
\hline Bone Sounding & $7 \mathrm{~mm}$ & $7 \mathrm{~mm}$ & $7 \mathrm{~mm}$ \\
\hline
\end{tabular}

Figure 3. Periodontal chart treatment planed and bone sounding for upper anterior region. From the measurement of pocket depth 11-15 =5 mm, and the bone sounding's measurement was $7 \mathrm{~mm}$. Based on that, the soft tissue that allowed to cut off was $2 \mathrm{~mm}$ to avoid biologic width violation. The rules also for 21-25.

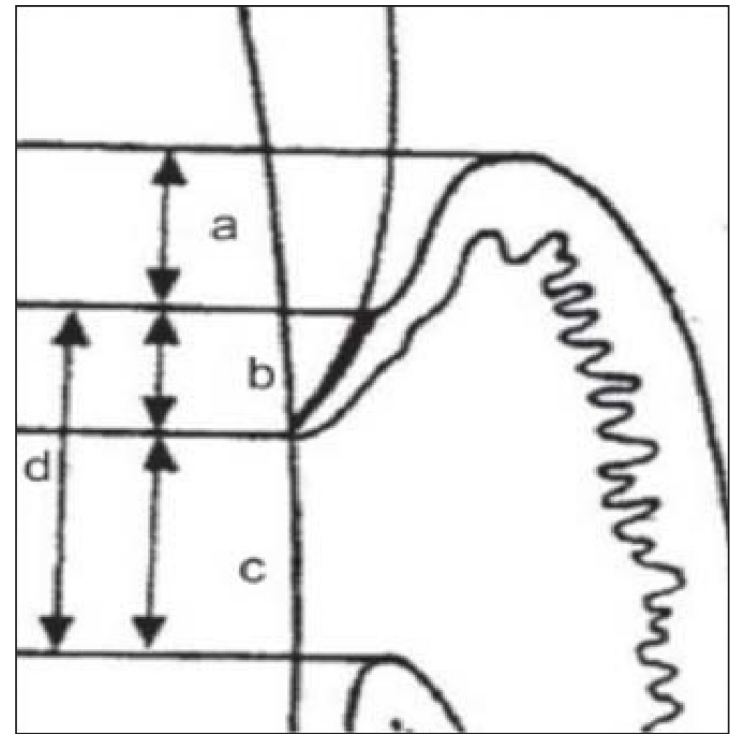

Figure 4. ( $\mathrm{a}=$ histological gingival sulcus), $(b=$ Ephitelial attachment $),(c=$ Connective tissue attachment $),(\mathrm{d}=\text { Biologic width }(\mathrm{b}+\mathrm{c}))^{1}$ A sulcus depth of 0,69 $\mathrm{mm}$ (a), an ephitelial attachment of 0,97 mm, and a connective tissue attachment of 1,07 mm. Based on that, the biologic width is commonly stated to be 2,04 $\mathrm{mm}$, which reperesent the sum of the epithelial and connective tissue measurement $(b+c)$.
Case 2: A male patient, 24 years old, presented a gingival enlargement in upper front teeth. Clinical examinations revealed Papillary Bleeding Index (PBI) 0,00, Plaque Index (PI) 1,03, Calculus Index (CI) 0,9 with a fibrotic gingiva at upper right anterior site due to treated with fixed orthodontic (Fig. 5) with anterior deep bite. Patient in good health condition without systemic condition. In this case, diagnosis was determined and also for treatment planed and surgical treatment. Scaling and dental health education was applied at initial phase periodontal treatment planning along with maintenance phase. After maintenance phase then gingivectomy was applied at surgery phase (phase II) of periodontal treatment (Fig. 6). Diagnosis was gingival enlargement by plaque and calculus with aggravated factors orthodontic force and deep bite in anterior region. Bone sounding for 13-23 $=6 \mathrm{~mm}$ was performed by probe under local anesthesia, $\mathbf{a}=\mathbf{4}, \mathbf{d}=\mathbf{2}$, then the structure of the tooth be exposed is $\mathbf{2} \mathbf{m m}$ (Fig. 7). Gingivectomy surgery by surgical blade no. 15 along with alveolectomy by using round bur to gain esthetic result after treatment periodontal surgery procedure also to decrease the effect of orthodontic force. Some clinicians prefer to use diode laser instead of sharp instrument due to more intraoperative homeostasis and comfortably for the patient. 


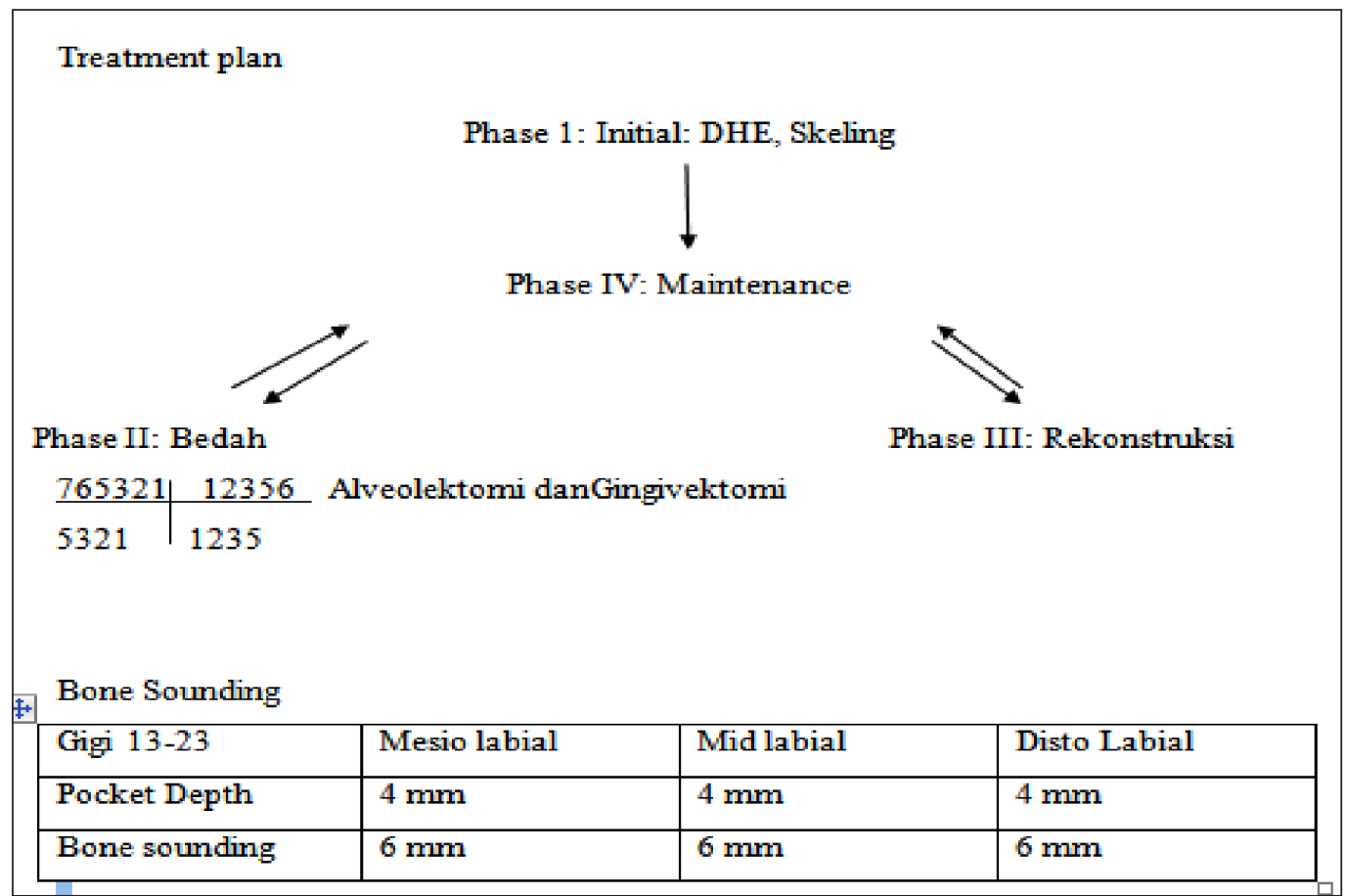

Figure 6. Periodontal chart treatment planed and bone sounding for upper anterior region. From the measurement of pocket depth 13-23 = $4 \mathrm{~mm}$, and the bone sounding's measurement was $6 \mathrm{~mm}$. Based on that, the soft tissue that allowed to cut off to exposed tooth structure was $2 \mathrm{~mm}$ to avoid biologic width violation.
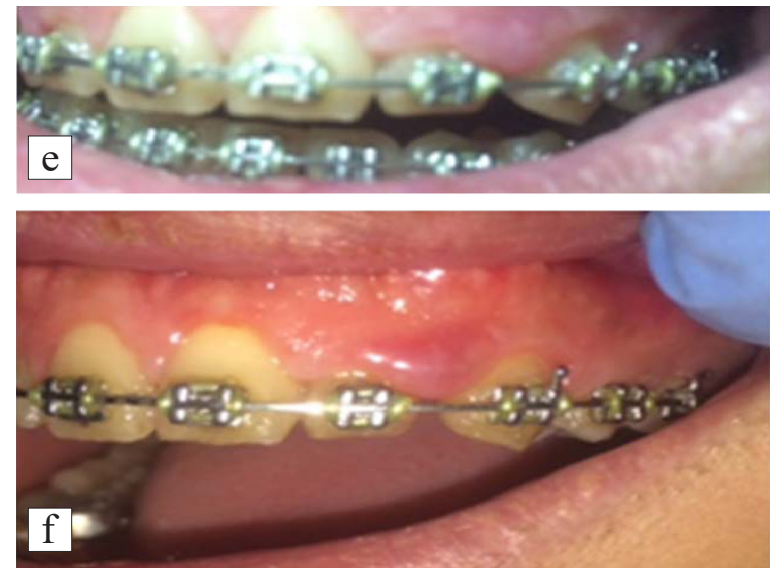

Figure 5. (e-f) Clinical examinations showed a condition of gingiva at upper anterior region which is fibrous and oedem with aggravated factors orthodontic force and anterior deep bite.

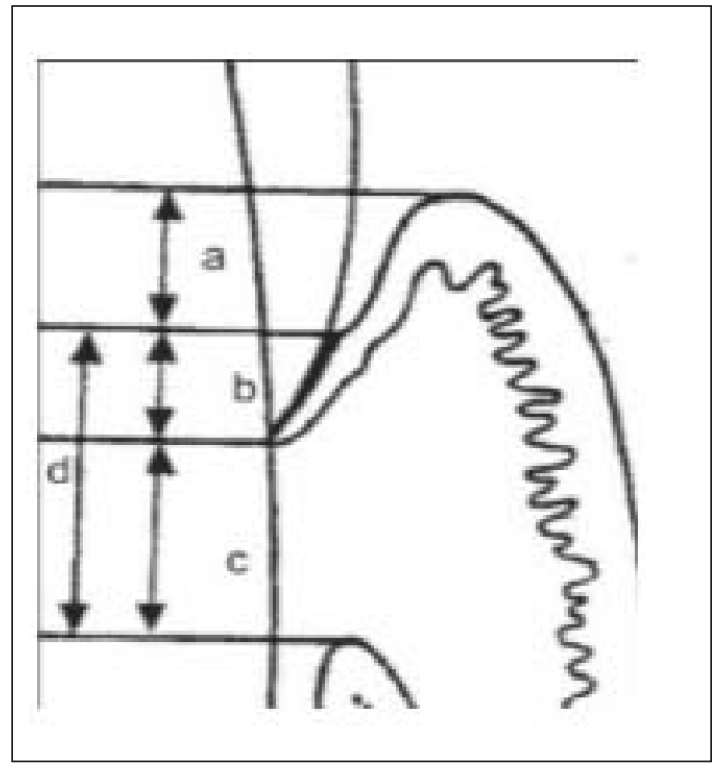

Figure 7. ( $\mathrm{a}=$ histological gingival sulcus), $(b=$ Ephitelial attachment $),(c=$ Connective tissue attachment $),(d=\text { Biologic width }(b+c))^{1}$ A sulcus depth of $0,69 \mathrm{~mm}$ (a), an ephitelial attachment of $0,97 \mathrm{~mm}$, and a connective tissue attachment of $1,07 \mathrm{~mm}$. Based on that, the biologic width is commonly stated to be $2,04 \mathrm{~mm}$, which reperesent the sum of the epithelial and connective tissue measurement $(b+c)$. 


\section{DISCUSSION}

The dimension of the biologic width can be vary based on the position of tooth, from tooth to tooth and from surface on the same tooth. Invasion of the biologic width due to other treatment that involving gingiva such as restoration or orthodontic treatment could result localized gingival hyperplasia or fibrotic with minimal bone loss. ${ }^{9}$ Gingivectomy surgery with the concept of biologic width is selected for the case in periodontal disorders with gingival enlargement. This clinical case clearly illustrates the gingivectomy surgery with esthetic demands with recontouring gingiva. The instrument used to accomplish tbe gingival recontouring-knife. This result is dictated by the level of the underlying alveolar crest. ${ }^{10}$

\section{CONCLUSION AND SUGGESTION}

The aim of this reports was to provide a diagnostic rationale for gingival recontouring. When gingivectomy is determined, the concept of biological width must be applied to achieve a harmonious gingival contour with an optimal oral hygiene maintenance. Repeated maintenance visits, patient co-operation and motivation are important for gained success of this procedure with pristine periodontal health.

\section{REFERENCES}

1. Verma SC, Govila V, Govila S, Mohan S. Determination of Biologic Width and Its Relevence in Periodontics And Restorative Dentistry. Indian Journal of Dental Sciences. 2015;7(2):106-109.
2. Khuller N, Sarma N. Biologic Width: Evaluation and Correction of its Violation. J. Oral Health Comm Dent. 2009;3(1):20-25

3. Jorgic-Srdjak K, Plancak D, Maricevic T, Dragon M, Bonsjak A. Periodontal and prosthetic aspect of biological width part I: Violation of biologic width. Acta Stomatol Croat. 2000;34:197-197.

4. Jorgic-Srdjak K, Dragon M, Bonsjak A, Plancak D, Filipovic I, Lazic D. Periodontal and prosthetic aspect of biologic width part II: Reconstruction of anatomy and function. Acta Stomatol Croat. 2000;34:441-444.

5. Smukler H, Chaibi M. Periodontal and Dental Consideration in Clinical Crown Extension: A Rationale basis for treatment. Int $J$ Periodont Restor Dent. 1997; 17:464-477.

6. Eid HA, Assiri HAM, Kandyala R, Togo RA, Turakhia VS. Gingival Enlargement in Different Age Groups during Fixed Orthodontics Treatment. Journal of International Oral Health. 2014;6(1):1-4.

7. Surlin P, Rauten AM, Mogoanta L, Silosi I, Opera B, Pirici D. Correlation between the gingival crevicular fluid MMP8 levels and gingival overgrowth in patiens with fixed orthodontic devices. Romanian Journal of Morpholog. 2010;51(3):515-519.

8. Kokich VG. The Role of Orthodontic as an adjunct to periodontal therapy. In: Newman MG, Takei HH, Carranza FA, eds. Clinical Periodontology 9ed. Philadelphia: Saunders; 2003:704-705.

9. Ganji KK, Patil VA. A Comparative Evaluation for Biologic Width following Surgical Crown Lengthening using Gingivectomy and Ostectomy Procedure. International Journal of Dentistry. 2012:1-9.

10. Shoba KS, Mahantesha, Sesha H, Mani R, Kranti K. Clinical evaluation of the biologic width following surgical crown lengthening procedure. A prospective study. J Indian Soc. Periodontol. 2010;14:160-167. 